\title{
2004 METU EUROPOS ČEMPIONATO RANKININKŲ KŪNO KOMPOZICIJOS, VARŽYBINĖS PATIRTIES, AMŽIAUS RODIKLIŲ SĄSAJA SU SPORTINIAIS REZULTATAIS
}

\author{
Antanas Skarbalius \\ Lietuvos kūno kultūros akademija, Kaunas, Lietuva
}

\begin{abstract}
Antanas Skarbalius. Docentas socialinių mokslų habilituotas daktaras, Lietuvos kūno kultūros akademijos Sporto technologijų katedroje e. prof. p. Mokslinių tyrimų kryptis — sportininkų rengimo valdymo modeliavimas.
\end{abstract}

\begin{abstract}
SANTRAUKA
Matematinès statistikos metodais buvo tirta 2004 metu Europos vyru rankinio čempionato 16 šaliu rinktiniu $(n=254)$ nariu ügio, svorio, varžybinès patirties, amžiaus rodikliu poveikis sportiniams rezultatams. Duomenys paimti iš oficialiu dokumentu. 2004 metu Europos čempionato rungtyniu sèkmę daugiausia lèmé žaidèju amžius $(r=0,565$; $\left.r^{2}=0,3196\right)$. Čempionato dalyviu amžiaus vidurkis - 28,3 $\pm 3,9$ metu. Visi aukštesnes vietas (1-8) užémusiu rinktiniu nariai, išskyrus ketvirtos vietos laimètojus Kroatijos rankininkus, buvo vyresni negu čempionato dalyvis vidutiniškai. Čempionato dalyvis rinktineje vidutiniškai buvo žaidęs $86,5 \pm 62$ rungtynes. Varžybinès patirties (šalies rinktinėje žaistu rungtyniu skaičius) rodiklis taip pat turëjo ¿̇takos $\left(r^{2}=0,2561\right)$ aukštesnès vietos užèmimui. Daugiau galimybiu laimèti rungtynes turèjo tos rinktinès, kuriu žaidèju patirtis buvo didesne $(r=0,506)$. Čempionato žaidèju varžybinę patirtí lèmé ju amžius $(r=0,753)$. Nors tarp užimtu vietu ir ügio rodikliu nustatyta tiesinè priklausomybé, tačiau šiek tiek aukštesnio ūgio žaidèju rinktinès didesniu galimybiu laimèti rungtynes ir užimti aukštesnę galutine vieta šiame čempionate neturejo $\left(r^{2}=0,0161\right)$. Čempionato dalyviu ūgio vidurkis $-191,1 \pm 5,7 \mathrm{~cm} .2004$ metu Europos čempionate žaidèju svoris turèjo reikšmingesnę itaka $\left(r^{2}=0,2561\right)$ sèkmingai rungtyniu baigčiai negu ūgis. Čempionato dalyviu svorio vidurkis - 92,5 \pm 4,7 kg. Vidutinis čempionato dalyviu kūno masès indeksas - 25,3. 2004 metu Europos čempionate reikšmingesni buvo varžybinès patirties, o ne kūno konstitucijos rodikliai. Šiu rodikliu reikšmé priklauso nuo konkuruojančiu komandu žaidèju kitu parengtumo požymiu skirtingumo.
\end{abstract}

Raktažodžiai: rankinis, parengtumas, kūno kompozicija, varžybinè patirtis.

\section{IVADAS}

$\mathrm{M}$ anoma, kad rankininkų kūno kompozicija (ūgis ir kūno svoris) turi reikšmès siekiant laimèti rungtynes - didesnio svorio rankininkai stipriau meta $\mathfrak{i}$ vartus, geriau valdo kamuoli, laimi dvikovas su varžovu, aukštesni žaidejjai geriau ginasi ir veiksmingiau atakuoja varžovu vartus (Jeschke, 1981, 1995; Taborsky, 1993). Rankininkų kūno kompozicijos svarbą patvirtino pasaulio elito - Prancūzijos (Constantini, 1998), Rusijos (Maksimov, 1998), Švedijos (Johansson, 1998) vyrų rankinio rinktinių treneriai, tačiau olimpinių žaidynių tyrimais tokių dėsningumų nenustatyta (Skarbalius, 2002, 2003a). Rankininkų varžybinès veiklos rodikliai glaudžiai susiję su sportininkų patirtimi. Rankinio ekspertai (Constantini, 1998; Johansson, 1998) teigia, kad kasmet rinktineje kiekvienas narys turi žaisti 20-50 rungtynių. Sportininkas pasirengęs atstovauti rinktinei, kai joje yra žaidęs per 50 tarptautinių rungtynių ir pelnęs per 300 ịvarčių. Olimpinèse žaidynèse brandesnio amžiaus ir didesnès varžybinès patirties rankininkai turèjo 
daugiau galimybių laimèti rungtynes ir užimti aukštesnę vietą (Skarbalius, 2002). Dinamiškèjant rankinio žaidimui (Skarbalius, 2000, 2002, 2003), ypač aktualu nuolat stebėti ir nustatyti, kaip sportinius rezultatus veikia rankininkų kūno kompozicijos, varžybinès patirties, kurią lemia ir amžius, rodikliai.

Tyrimo tikslas - nustatyti rankininku kūno kompozicijos, varžybinès patirties, amžiaus rodiklių poveiki 2004 metų Europos čempionato sportiniams rezultatams.

Tyrimo metodika ir organizavimas. Atliekant tyrimą taikyta:

1. Dokumentų ir literatūros analizè.

2. Matematinès statistikos metodai (aritmetinis vidurkis, standartinis nuokrypis, vidurkių skirtumų reikšmingumas pagal $t$ Stjudento nepriklausomų imčių kriterijų, koreliacijos ryšiai). Buvo įvertinti 16 šalių rinktinių $(\mathrm{n}=254)$ dalyvių ūgio, svorio, amžiaus, varžybinès patirties (žaistų rungtynių skaičius šalies rinktinèje) rodikliai.

3. Lyginamoji analizè.

Duomenys apie šalių rinktinių žaidejjus gauti iš oficialių dokumentų (Men's European Handball Championship (2004). CD-ROM. Viena: EHF.).

\section{REZULTATAI}

Ūgis. Čempionato dalyvių ūgio vidurkis $191,1 \pm 5,7 \mathrm{~cm}$ (1 pav.). Aukščiausi buvo Vokietijos rinktinès rankininkai $(195,4 \pm 6,8)-4,4 \mathrm{~cm}$ aukštesni negu vidutinio ūgio čempionato dalyvis $(\mathrm{p}<0,05)$, žemiausi $-4,6 \mathrm{~cm}$ žemesni negu vidutinio ūgio čempionato dalyvis $(\mathrm{p}<0,001)$ Portugalijos rankininkai $(186,5 \pm 4,5)$. Tarp aukštesnes $(1-8)$ bei žemesnes $(9-16)$ vietas užèmusių rinktinių keturios turèjo aukštesnius ir keturios žemesnius nei vidutinio ūgio čempionato dalyvius. Vis dèlto aukso (Vokietijos) ir sidabro (Slovėnijos) medalius laimejjusių rinktinių žaidejjai buvo aukštesni $(p<0,05)$ negu turnyro dalyvis vidutiniškai.

Svoris. Čempionato dalyvių svorio vidurkis 92,5 $\pm 4,7 \mathrm{~kg}$ (2 pav.). Tarp aukštesnes vietas $(1-8)$ užèmusių rinktinių keturių rankininkai buvo sunkesni ir keturiu lengvesni negu turnyro dalyvis vidutiniškai. Aukso (Vokietijos) ir sidabro (Slovènijos) medalius laimejjusių rinktinių žaidejai buvo sunkesni - atitinkamai 1,5 ir $2 \mathrm{~kg}$ negu turnyro dalyvis vidutiniškai. Tarp žemesnes (916) vietas užèmusių rinktinių trijų - Vengrijos $(\mathrm{p}<0,01)$, Ispanijos, Čekijos — žaidejai buvo sunkesni, triju - Šveicarijos $(\mathrm{p}<0,01)$, Islandijos $(\mathrm{p}<0,01)$, Ukrainos - lengvesni negu vidutinio svorio čempionato dalyvis, o Portugalijos ir Lenkijos - tokio pat svorio kaip ir turnyro dalyvis vidutiniškai.

Kūno masès indeksas. Vidutinis čempionato dalyvių kūno masès indeksas (KMI) - 25,3. Tarp aukštesnes vietas užèmusių rinktinių keturių Slovėnijos, Kroatijos, Prancūzijos, Serbijos ir Juodkalnijos - žaidèjų rodikliai buvo didesni, triju — Vokietijos, Rusijos, Švedijos - mažesni ir bronzos medalius laimejjusių Danijos rankininkų KMI atitiko vidurkį. Tarp žemesnes vietas užèmusių rinktinių triju — Vengrijos, Čekijos ir Portugalijos — rankininkų rodikliai buvo didesni negu vidutiniški, kitu - mažesni.

Amžius. Čempionato dalyvių amžiaus vidurkis $-28,3 \pm 3,9$ metai ( 3 pav.). Visi aukštesnes vietas $(1-8)$ užèmusių rinktinių rankininkai buvo vyresni negu čempionato dalyvis vidutiniškai. Tik ketvirtos vietos laimètojos Kroatijos rinktinès
1 pav. 2004 m. Europos čempionato vyrų rankinio rinktinių žaidèjų úgio rodikliai $(\bar{\chi} \pm S D)$
Pastaba. ${ }^{*}-\mathrm{p}<0,05,{ }^{* *}-\mathrm{p}<0,01,{ }^{* * *}-$ $\mathrm{p}<0,001$ skirtumo reikšmingumo lygmuo, lyginant su vidutine reikšme.

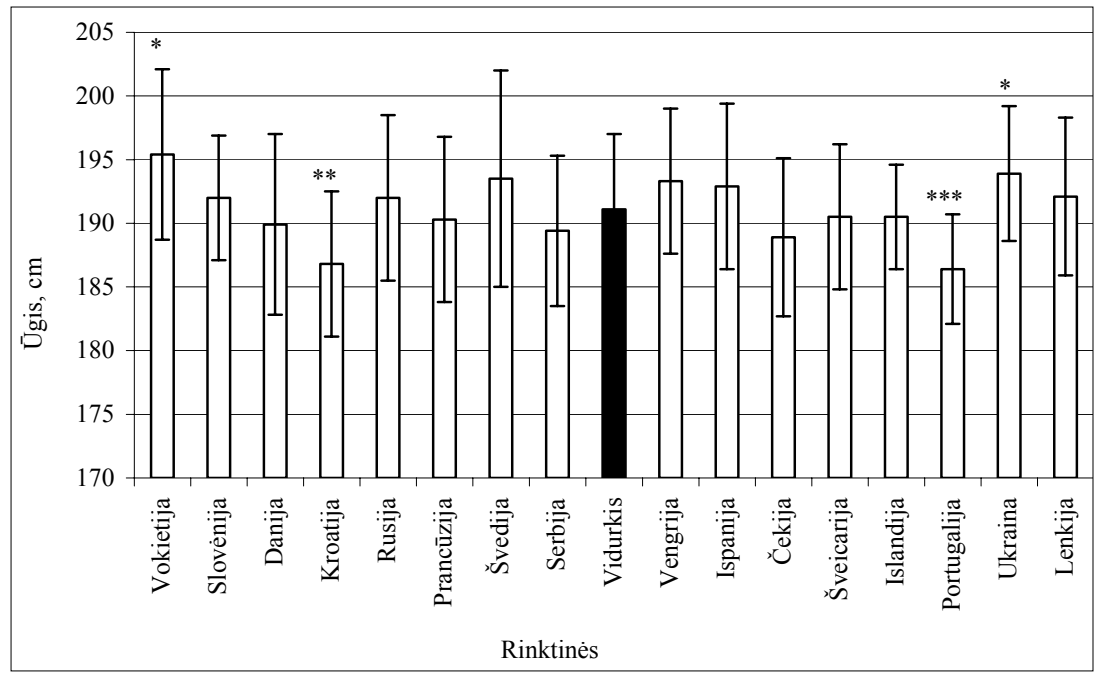



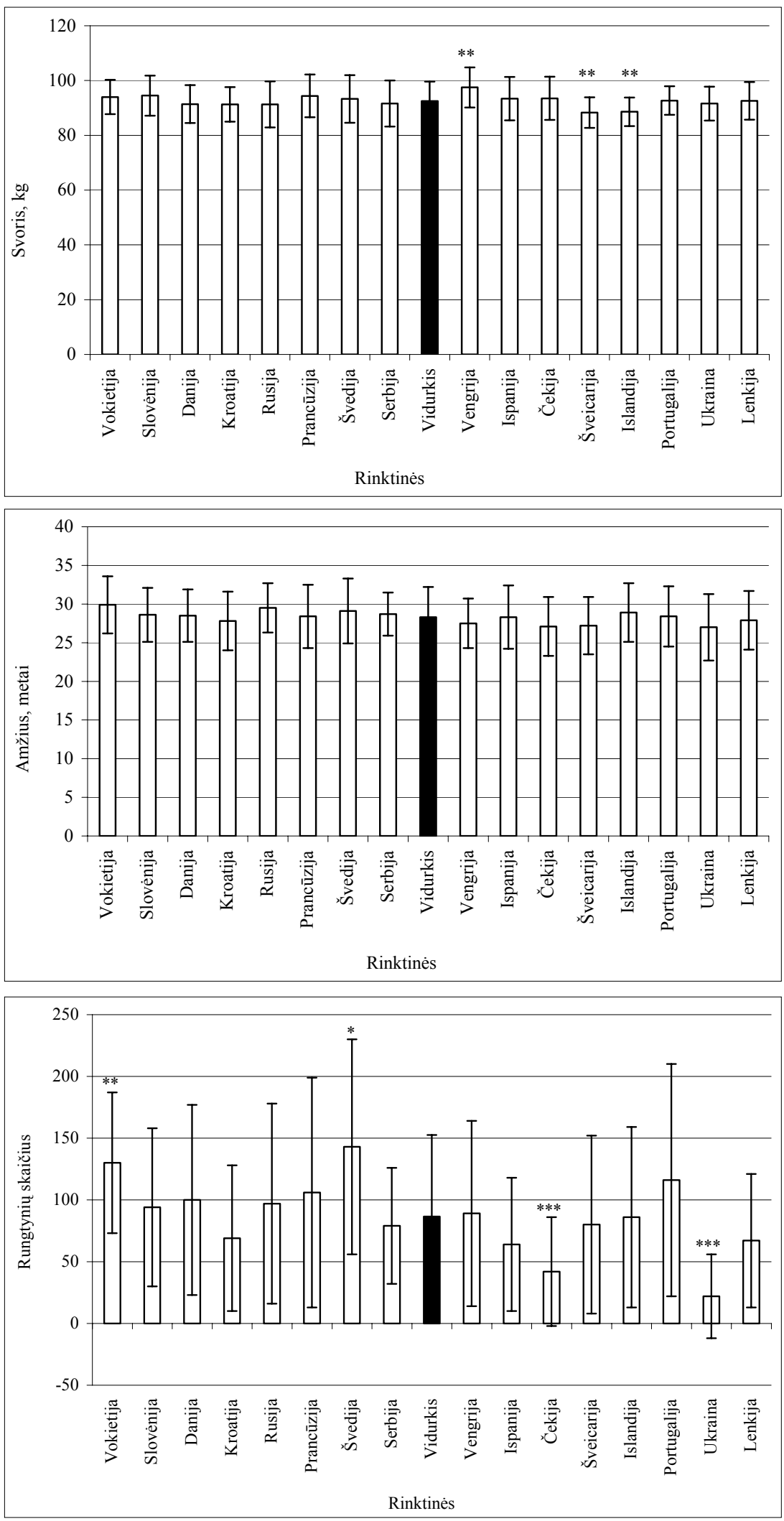

2 pav. $2004 \mathrm{~m}$. Europos čempionato vyrų rankinio rinktinių žaidèjų svorio rodikliai $(\bar{\chi} \pm S D)$

Pastaba. ${ }^{* *}-\mathrm{p}<0,01$ skirtumo reikšmingumo lygmuo, lyginant su vidutine reikšme.

3 pav. 2004 m. Europos čempionato vyrų rankinio rinktinių žaidèjų amžiaus rodikliai $\left(\bar{\chi}_{ \pm} \mathrm{SD}\right)$

4 pav. 2004 m. Europos čempionato vyru rankinio rinktinių žaistų rungtynių rodikliai $(\overline{\mathrm{X}} \pm \mathrm{SD})$

Pastaba. ${ }^{*}-\mathrm{p}<0,05,{ }^{* *}-\mathrm{p}<0,01,{ }^{* *}-$ $\mathrm{p}<0,001$ skirtumo reikšmingumo lygmuo, lyginant su vidutine reikšme.

žaidèjai $(27,8 \pm 3,8)$ buvo 0,5 metų jaunesni nei turnyro dalyvis vidutiniškai. Tarp žemesnes vietas (9-16) užèmusių rinktiniu vyresni buvo 13 vieta laimèję Islandijos rankininkai $(28,9 \pm 3,8)$, o 10 vietą užèmusios Ispanijos $(28,3 \pm 4,1)$ ir 14 vietą užėmusios Portugalijos $(28,4 \pm 3,9)$ rankininkai buvo tokio paties amžiaus kaip ir turnyro vidutinio amžiaus žaidèjai. Vyriausi čempionai - Vokietijos rankininkai $(29,9 \pm 3,7)$, jauniausi -15 vietą užèmusios Ukrainos rinktinès žaidejai $(27 \pm 4,3)$.

Varžybinè patirtis - žaistos rungtynès rinktinèje. Čempionato dalyvis rinktinejje vidu- 
tiniškai buvo žaidęs $86,5 \pm 62$ rungtynes (4 pav.). Didžiausią patirti turèjo čempionai - Vokietijos $(130 \pm 57 ; p<0,01)$ ir septintą vietą užèmę Švedijos $(143 \pm 87 ; p<0,05)$ rankininkai. Tarp aukštesnes vietas užèmusių rinktinių šiek tiek $(p>0,05)$ mažesnę patirti turèjo Kroatijos bei Serbijos ir Juodkalnijos rinktinių žaidejai. Tarp žemesnes vietas užèmusių rinktinių didesnès patirties nei turnyro dalyvis vidutiniškai buvo Portugalijos žaidejjai, o Vengrijos ir Islandijos jos turejo tiek pat, kaip ir čempionato dalyvis vidutiniškai. Mažiausios patirties buvo 15 vietą užėmusios Ukrainos $(22 \pm 34$; $p<0,001)$ rankininkai. Statistiškai patikimai mažesnès patirties negu turnyro dalyviai vidutiniškai buvo ir Čekijos rinktinès žaidejjai $(42 \pm 44 ; \mathrm{p}<0,001)$.

\section{REZULTATŲ APTARIMAS}

Čempionato žaidèjų varžybinę patirtị lèmé jų amžius $(r=0,753)$. Galima manyti, kad brandesnio amžiaus rinktinių žaidèjai buvo ir dèl daugiamečio sportininkų rengimo paskutiniu olimpinio ciklo metų ypatumų. Be to, šis Europos čempionatas buvo ir paskutinis Atenu olimpinių žaidynių atrankos etapas. Paprastai rinktinès yra atjauninamos olimpinio ciklo pradžioje ir per ketverius jo metus siekiama padidinti žaidejuc varžybinę patirti (Czerwinski, 1996; Constantini, 1998). Toki teigini patvirtina 2000 (Skarbalius, 2000) $(27,5 \pm 3,9)$ ir 2004 metų Europos čempionatų dalyvių statistiškai patikimas amžiaus rodikliu skirtumas $(p<0,05)$. Be to, šio čempionato dalyviai buvo 0,5 metu vyresni negu 2002 metu Europos čempionato dalyviai (Skarbalius, 2003). Sèkmingą 2004 metu Europos čempionato rungtynių baigti daugiausia lèmé žaidèjų amžius $(r=0,565)$. Determinacijos koeficientas $\left(r^{2}=0,3196\right)$ patvirtina ši teigini (5 pav.). Vien dèl šios priežasties Europos šalių rinktinès, išskyrus Portugalijos, negalèjo sèkmingiau pasirodyti ir užimti aukštesnès nei 816 vietos. Portugalijos rinktinès nariu žaidimui galèjo turèti ittakos ir kiti tyrinèti veiksniai šios šalies žaidejjai buvo statistiškai reikšmingai $(\mathrm{p}<0,001)$ žemesnio ūgio nei turnyro dalyvis vidutiniškai.

Varžybinès patirties (šalies rinktinejje žaistų rungtynių skaičius) rodiklis taip pat turejo ittakos $\left(r^{2}=0,2561\right)$ aukštesnès vietos užèmimui (6 pav.). Daugiau galimybių laimèti rungtynes turèjo tos rinktinès, kuriu patirtis buvo didesnè $(r=0,506)$.
Tarp žemesnę 8-16 vietą užėmusių rinktinių tik Portugalijos rinktinès žaidèjai buvo didesnès patirties negu turnyro dalyvis vidutiniškai. Aukštesnes vietas užèmusių rinktinių žaidèjai buvo rinktinėje žaidę daugiau kaip 50 rungtynių. Gauti rezultatai patvirtino D. Constantini (1998) ir F. Taborsky (1998) teigini, kad žaidejjai, rinktinèje žaidę per 50 rungtynių, yra pasirengę atstovauti šaliai. Lyginant 2000 (Skarbalius, 2000), 2002 (Skarbalius, 2003) ir 2004 metu Europos čempionatu rodiklius, žaideju patirties rodikliai statistiškai reikšmingai nesiskyrè. Vadinasi, vidutiniškai visų Europos šalių rinktinių žaidèjų patirtis yra didelè. Tarp konkuruojančiu rinktinių žaidèju patirties rodiklis buvo reikšmingas. Tai patvirtino pastarojo čempionato sportiniai rezultatai.

2004 metų Europos čempionato dalyviai vidutiniškai buvo $0,5 \mathrm{~cm}$ aukštesni negu 2000 metu (Skarbalius, 2000) ir $0,4 \mathrm{~cm}$ aukštesni negu 2002 metu (Skarbalius, 2003) čempionatu dalyviai, nors skirtumas ir nèra statistiškai patikimas. Kai kurie mokslininkai tvirtina ūgio rodikliu svarbą galimybei laimèti rungtynes (Jeschke, 1981, 1995; Taborsky, 1993, 1998), tačiau nustatytas kontroversiškas tarpusavio ryšys olimpinèse žaidynèse (Skarbalius, 2002, 2003) neleidžia kalbèti apie dèsningumus. Tarp 2004 metų Europos čempionato rinktinių, užèmusių ir aukštesnes, ir žemesnes vietas, buvo aukštesnių ir žemesnių nei vidutinio ūgio žaidèjų (3 pav.). Nors tarp užimtų vietų ir ūgio rodiklių yra tiesinè priklausomybè (7 pav.), šiek tiek didesnis rinktinès žaideju ūgis lemiamos itakos laimèti rungtynes ir užimti aukštesnę galutinę vietą šiame čempionate neturèjo $\left(\mathrm{r}^{2}=0,0161\right)$.

2004 metų Europos čempionate žaidèjų svoris didesnès reikšmès laimèti rungtynes turèjo $\left(\mathrm{r}^{2}=0,2561\right)$ negu ūgis ( 8 pav.). Tarp aukštesnes ir žemesnes vietas užèmusių rinktinių buvo beveik vienodas skaičius didesnio ir mažesnio svorio žaidèjų negu turnyro dalyvis vidutiniškai. Vadinasi, šis rodiklis čempionato rinktinėms ypatingo pranašumo nesuteikè. Tokie rezultatai patvirtina gautų tyrimų kontroversiškumą: vieneriose varžybose svorio rodikliai reikšmingi (Jeschke, 1981, 1995; Skarbalius, 2002), kitose - ne (Skarbalius, 2003 b). Šio čempionato dalyviai buvo $1,4 \mathrm{~kg}$ lengvesni negu 2000 metu (Skarbalius, 2000) ir 1,3 kg sunkesni negu 2002 metų (Skarbalius, 2003) čempionatų dalyviai. 


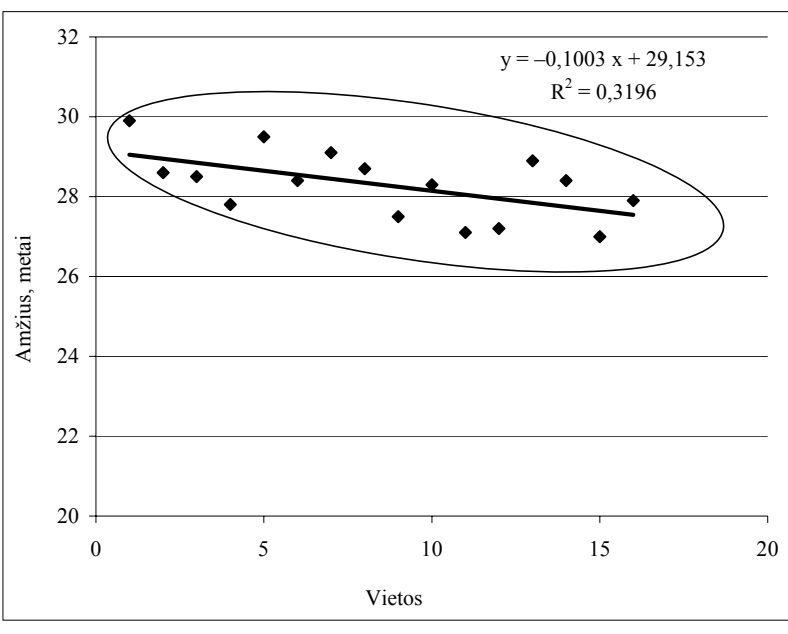

5 pav. 2004 m. Europos čempionato vyrų rankinio rinktinių žaidèjų amžiaus ir čempionate užimtų vietų tarpusavio ryšys

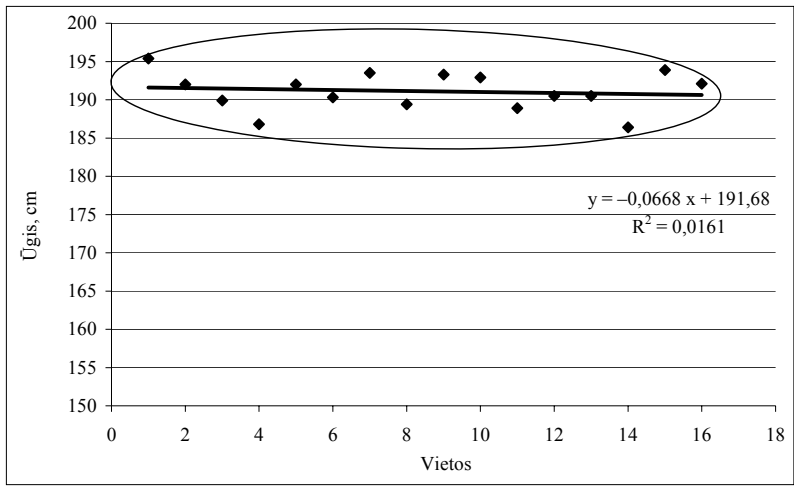

7 pav. 2004 m. Europos čempionato vyrų rankinio rinktinių žaidèjų ūgio ir čempionate užimtų vietų tarpusavio ryšys

\section{IŠVADOS}

Apibendrinant galima teigti, kad 2004 metu Europos čempionate varžybų laimèjimą daugiau lèmè varžybinès patirties, o ne kūno konstitucijos

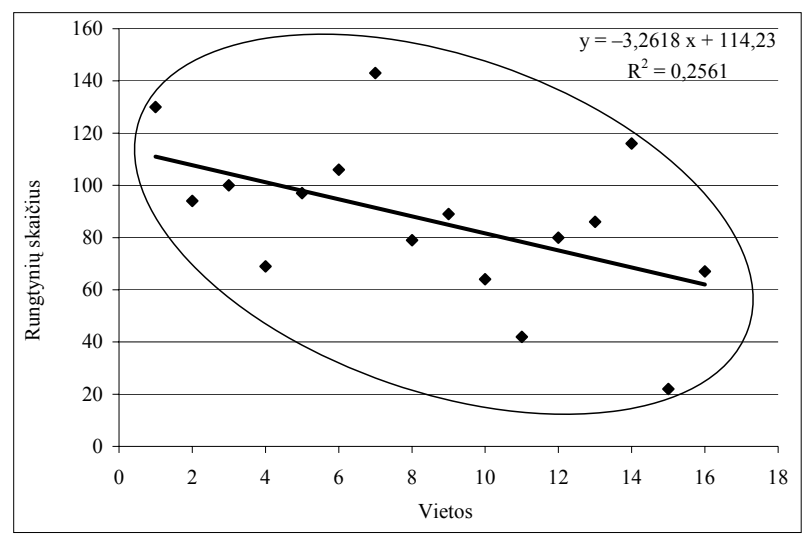

6 pav. $\mathbf{2 0 0 4} \mathbf{m}$. Europos čempionato vyrų rankinio rinktinių žaidèjų patirties ir čempionate užimtų vietų tarpusavio ryšys

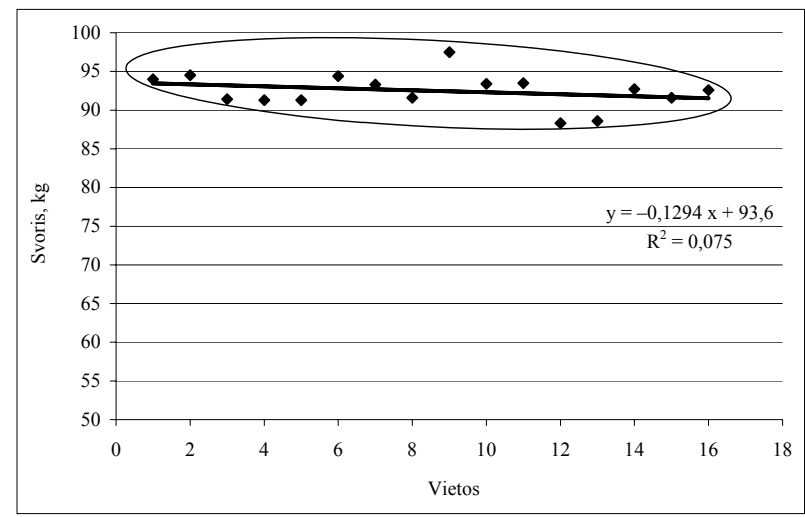

8 pav. 2004 m. Europos čempionato vyrų rankinio rinktinių žaidèjų svorio ir čempionate užimtų vietų tarpusavio ryšys

rodikliai. Šiu rodikliu reikšmė priklauso nuo konkuruojančių komandų žaidèjų kitų sportinio parengtumo požymių skirtingumo.

\section{LITERATŪRA}

Constantini, D. (1998). La journée d'entraînement au sein de l'équipe nationale. Vienna: EHF.

Czerwinski, J. (1996). Metodyczne i badawccze aspekty procesu wieloletniego treningu piłkarcy ręcznych. Gdansk: Akademia Wychowania Fizycznego.

Jeschke, J. (1995). Anthropological characteristics of the top handball players - 1995 World Championship, Iceland. Sports Medicine and Handball II. Basel: IHF.

Jeschke, J. (1981). Antropometrische Charakteristik der Handballspieler/innen am Olympischen Turnier 1980. Internationales Trainer Symposium, Magglingen. Basel: IHF.

Johansson, B. (1998). The preparation of the Swedish Team for this Championship. EHF Seminar Coach Meets Coach. Seminar documentation. Vienna: EHF.
Maksimov, V. (1998). Der Gegenstoß. Vienna: EHF. Men's European Handball Championship. (2004). CDROM. Vienna: EHF.

Skarbalius, A. (2003 a). Didelio meistriškumo rankininku rengimo optimizavimas: habilitacinis darbas. Kaunas: LKKA.

Skarbalius, A. (2000). Europos vyrų rankinio - 2000 modelis. Ugdymas. Kūno kultūra. Sportas, 2 (35), 5358.

Skarbalius, A. (2003). Europos vyrų rankinio' 2002 modelis. Ugdymas. Kūno kultūra. Sportas, 3 (48), 51-57.

Skarbalius, A. (2002). Olimpinis vyru rankinis: ypatumai ir tendencijos. Kaunas: LKKA.

Skarbalius, A. (2003 b). Peculiarities of elite and Lithuanian men's handball. In W. Starosta, W. Osinski 
(Eds.), Conference of International Association of Sport Kinetics. New Ideas in Sport Sciences: Current Issues and Perspectives. Part 1. (pp. 243-247). Warsaw Poznan - Leszno: State School of Higher Vocational Education.
Taborsky, F. (1993). Papers for the Lecture at the International Trainer Symposium of the IHF. Diuseldorf.

Taborsky, F. (1998). Selected characteristics of the Men's European Championship participants. Handball, Periodical for Coaches, Referees and Lecturers, 2 (8), 4-9.

\title{
THE INTERACTION BETWEEN THE INDICES OF BODY COMPOSITION, COMPETITIVE EXPERIENCE, AGE OF HANDBALL PLAYERS AND THEIR SPORTS RESULTS IN MEN'S EUROPEAN HANDBALL'2004
}

\author{
Antanas Skarbalius \\ Lithuanian Academy of Physical Education, Kaunas, Lithuania
}

\begin{abstract}
The aim of the research was to investigate the interaction between the indices of players' body composition, competitive experience, age and sports results in the European Men's Handball Championship 2004. The data from official statistical documents were taken and statistical analyses (means, standard deviation, correlation) of 264 subjects were used. The age $(28.3 \pm 3.9)$, height $(191.1 \pm 5.7 \mathrm{~cm})$, weight $(92.5 \pm 4.7 \mathrm{~kg})$, body mass index (25.3), competitive game experience $86 \pm 62$ of participants in average were measured. The competitive experience $\left(r^{2}=0.2561\right)$, age $\left(r^{2}=0.3196\right)$ had significant influence in winning the match. The interaction was found out between the height $\left(\mathrm{r}^{2}=0.0161\right)$ and the results. The weight had more significant influence $\left(r^{2}=0.2561\right)$ than the height in winning the match. The competitive experience and age related to those indices had more influence in winning the match and took higher places than the body composition (height and weight).
\end{abstract}

Keywords: handball, sports performance, body composition, competitive experience of players.

Lietuvos kūno kultūros akademija (Lithuanian Academy of Physical Education) Sporto g. 6, LT-44221 Kaunas Lietuva (Lithuania) Tel +370 37335114 E-mail a.skarbalius@lkka.lt 